\title{
Supply and Demand Drug Shortage Causes: Patient-centric Business Model and its Application
}

\author{
By Raimonda Bubliene*, Aurelija Burinskiene ${ }^{*}$
}

\begin{abstract}
In this study, the authors have investigated supply and demand drug shortage causes and highlighted the collaborative business model in solving drug shortages. The aim of this research is to build a collaborative business model helping to investigate how to deal with drug shortages. The authors have included employee and patient relationship into collaborative business model. Following the analysis of the evolution of the term "business model", it is noted that the evolution of the term is closely linked to the development of B2(B2B) (McGlinchey and Toews 2017). In scientific literature there are mentioned more than 50 elements of the concept structure of the business model. In the study authors provided patient-centric business model and selected 9 main structure elements connected to the areas of key resources, key activities, and value system. The study consists of three parts. In the first one, the paper discloses the concept of a business model and the evolution of business models. In the second part, address the importance of links between distribution channel partners to solve drug shortage causes in distribution channel. The legal regulation provided in a good practice of supply of medicine in the chain and the right of the patients were highlighted to access to the goods and services. In the third part, the application of business model scenario in the pharma sector that might guarantee high level of protection of human health is presented. Herein several medical distribution channel scenarios are compared and their influence on drug shortage is presented. The research study is based on time horizon and event tree analysis.
\end{abstract}

Keywords: Demand, Drug shortage, Employees, Patients' Rights, Supply

\section{Introduction}

Adler et al. (2011) in Harvard Business Review promoted collaborative enterprise build-up as best organizational form. It promotes shared purpose as social responsibility outlined by sociologist Max Weber. In particular, shared purpose articulates the position of enterprise towards suppliers, competitors and patient's society - it means unique labor force partnership for day-to-day process improvement. Collaborative purpose is defined as best service quality to customers delivery, i.e., it is what every employee is trying to do providing contribution to society.

Shortages of drugs put patients at risk to get most efficient health improvement. The study of US case (MediMedia 2011) that drug shortages are affected by supply and demand cases, which are pointed among 7 major problems destroying patients' welfare. Hence, it is important to ensure the rights of patients and patients' accessibility to health care, right of access to preventive health care and the right to benefit from medical treatment. As well, patients must be accorded qualified health care and patient's rights law is intended to secure good medical practice. Each of the national health systems of the EU countries manifests quite different realities with respect to patients' rights.

*PhD Student/Lecturer, Mykolas Romeris University/Vilnius Gediminas Technical University, Lithuania.

${ }^{\dagger}$ Associated Professor, Vilnius Gediminas Technical University, Lithuania. 
Pharmaceutical supply chain differs from traditional supply chain by environment and complexity. The attention is also drawn to the fact that pharmaceutical supply chain combats slowed growth and industry pressures. Pharmaceuticals enterprises must embrace demand-chain thinking and cloudenabled solutions to become more flexible and able to share data in real-time with partners, from producers, to specialized distributors and retailers. All these factors are compelling pharma businesses to rethink their supply chains and IT strategies and develop more collaborative business models that enable flexibility, speed, and compliance.

The study also extends research in the area. The study in year 2017 presented by Settanni et al. (2017) have promoted patient-centric delivery model, which has not been getting attention from academia until now but is important for the topic of drug shortage.

The study consists of three parts. The first part is dedicated to the concept of a business model - the operating model, which results the lowest possible the number of shortages. The evolution analysis of the term "business model" is observed and defined that the time evolution is closely related to collaboration revolution. The second part of the paper represents distribution channel as the system which meets patients needs. It addresses the importance of links between distribution channel partners to solve drug shortages in business and legal perspective. Finally, the authors presented the application of models in the pharma sector that might guarantee high level of protection of human health. Several distribution channel scenarios are presented here and their impact to shortage reduction. The research results showed the tendencies of application of smaller scale distribution channel and collaborative enterprises business models suggesting the future research directions in solving drug shortages.

\section{Literature Review}

Shortage Causes

On 2011 US agency has reported drug shortages crises and identified that $13 \%$ of causes are coming from supply and demand problems. The study of US case (MediMedia 2011) that drug shortages are affected by supply and demand cases, which are pointed among 7 major problems destroying patients' welfare. These are as follows: production difficulties, the unavailability of raw material, recalls, business and economic issues, regulatory issues, supply activity related issues and disasters.

\section{Supply side}

Disruption could be met in the supply of raw material. The shortages are painful when single supplier delays supply of raw material or cancels production and these actions affects many drug producers. Even the drug is produced by several producers, the raw material they buy from single seller (producer). 
Disruption of supply in this case will negatively affect all producers, which are manufacturing final product (i.e., drug) (Kleindorfer and Saad 2005).

Many producers of drugs are importing raw components from India, China and Europe. If some of these abroad suppliers has supply problems (Newman 2016) such as political, economic, historical (Coomber et al. 2016), environmental, etc., these could lead to shortage. The delays in supply of raw material leads to production overcrowded after the raw material is arrived. Economic reasons could lead producers to reduce level of inventory for low-revenue drugs or decide to discontinue production. There are some cases when producers take from the market drugs because they are giving low profits or the consumption is higher the capability of producer.

\section{Demand side}

The judge increase in demand could also lead to shortage, even if demand overcome production capacity. Producers usually use the same equipment to produce many drugs. So, they are not capable to rise production of single item without influencing shortage of others. In those cases, necessary to buy more equipment or contract other producers for production services. Such action requests time and temporally there is lag between supply fall period and finished production buildup in outsourced plants. Here are very important good ordering practices. To build them data accuracy and timeliness, transport and communication system efficiency is needed [for example, data about historical usage of product (Moreau 2017), access to inventory levels and reporting on hourly basis concerning freights and stocks must be foreseen (Hou et al. 2010)]. Even it is difficult to predict and be ready for daily shortage (Lopez et al. 2019), good planning (Sen et al. 2016) and reason-causes analysis (Simonsen et al. 2016) could help to reduce the number of shortage cases or to minimize the time period of shortfall.

\section{Collaborative Enterprises - New Business Model}

The concept of business model started to be used sufficiently. It is analyzed in the literature for innovation management, management, e-business, and enterprise strategy themes. Authors are still debating and offer different definitions of the business model. Most often, the business model is characterized as the creation of values for the client (i.e., patient). It describes how the company creates value for the customer. In addition, the business model reflects the business logic of the company, which shows what enterprise offers to its customers (i.e., patients), what is its relationship with its partners. The business model is as well as the way in which the enterprise can sustain itself.

Since the mid-1990, the increase in technology, especially in the value of information technology, has started to become an interest by scientists presenting its role in the concept of business model. Moreover, over the years, business models have become increasingly sophisticated and got high attention.

The literature analysis showed that more than 50 structural elements of a business model are met in the concept of the business model (Osterwalder and 
Pigneur 2002). Slywotzky (1995) proposed the broken-down pillars in the concept of business model, which are "what", "who", "how" and "how much". These four pillars allow to express the company offer to clients "what" (product innovation, value proposition, value blocks), "who" it targets (channels, mechanisms, relationship), "how" this can be realized (resources, activities, etc.) and "how much" can be earned by doing it (revenue streams, pricing mechanism, auction, pay-peruse, yield management, costs structure). These pillars consist of subsections and these sub-sections from structural elements.

In theory and practice, the business model is used to identify key business aspects: organizational structure (Alt and Zimmermann 2010), sales (demand forecasting) practices and business processes. Shafer et al. (2005) examined the concept of the business model and identified 42 structure elements of business model. A bit later, in 2012, Krumeich et al. (2012) counted more than 54 structural elements mentioned. Krumeich et al. (2012) criticizes the large number of elements of the structure, arguing that it is difficult to understand how all elements could be combined into unified system. These authors also mention that other authors who offer elements for the business model structure do not provide the guidelines for the formation of integrated business model system (Krumeich et al. 2012). Business models were mainly considered for internal purposes. An extension to external persons e.g., investors, was partially proposed (Shafer et al. 2005).

When carrying out the study, the authors selected 9 structural elements suitable for drugs distribution enterprises, where targeted customers are patients. On pillar level "what", "how much" pillars are not included into proposed business model as study is not concentrating on products innovation and financial assets. Other pillars "who" and "how" are included into the business model. The pillar "how" is presented on two axes, as infrastructure management must cover all elements linked with the configuration of activities and resources between the enterprise and its distribution channel partners in order to create value and reach patients. The authors of this paper fill the gap and provides business model elements for pharmaceutical supply chain enterprises. Below are elements selected for the business model:

- Channels - different channels could be selected for communication with customers (i.e., patients): off-line or on-line channels such as face-to-face or social media. There are also possible to use various types of channels: own channels and partner's channels or indirect channels and direct channels as well (McGill 2018).

- Mechanisms - scientists agree that the primary functions of business model are value creation and value capture. In general, there are four mechanisms such as value proposition and value targeting (generating value to patients through their willingness to pay), and value appropriation and value delivery (affecting business value through transactions' price and costs) (Biloshapka and Osiyevskyy 2018). Shortly, it could be treated as supply and demand matching mechanism working for pharmaceutical supply chain needs.

- Relationship - the relationships enterprise has with customers (i.e., patients) heavily impact their customer experience. It is product delivery in best way to 
the customers. Relationship could be tailored in many variants, like selfservice, dedicated assistance, automated service, etc. (McGill 2018).

- Employees - depends from the size of the company, but employees support organizational efficiencies (Armenakis and Bedeian 1999).

- Information - the enterprise must lever the data it possesses to information that can be used rapidly to facilitate knowledge creation and map effectively the complex many-to-many relationships existing between them (Alexopoulos and Theodoulidis 2003).

- Medicines and components - social aspect of health care business model is medicine and components. These are used to highlight exceptional specifics (Sabatier et al. 2017).

- Production - additive production growth is $34,9 \%$ in 2013 and current market volume of machinery and services of additive production is estimated at 3.7 billion euros. There are seven production steps: design and planning, material processing, machine preparation, physical production, post-processing, administration, and sales and quality (Schröder et al. 2015).

- Distribution is substantial logistics activity. It usually pertains the management of the material stream from production through a distribution channel to the end customer (Chapman et al. 2002).

- Product delivery is highlighted in health care and customer service topics and considered as a part of business model (Hwang and Christensen 2008). That is why the authors have included this element to proposed business model.

Gordijn and Akkermans (2001) propose a conceptual business model construction steps starting from actors, value exchanges, value activities, and value objects, and use these elements to model networked constellations of enterprises to end-consumers by separating creation, distribution, and consumption of things to economic value. The authors of this paper proposed to connect business model elements for drug distribution enterprises to the single system (Figure 1).

There are three axes: key activities, key resources and value system. Key activities support production, distribution, and product delivery processes. Key resources, like raw material, finished products placed to stock, information and employees are important in delivering activities. Employees and information are to support for material flow. All together have relational and transactional links and are integrated into value system, which delivers results to patient.

Each company has its own operations business model. The definition of business model covers: (1) the set of activities; (2) the set of departments (internal and external ones) executing activities; (3) the set of physical transactions between departments and human relationships among the managers of departments (as supervisors and/or connectors of departments); (4) the governance of control mechanisms implemented in departments and links between organizational units. In general, business model presents linkages between such systems: the system of activities, the system of resources, and the system of relationships between parties. 
Figure 1. Patient-centric Business Model with Elements for Drugs Demand and Supply Case

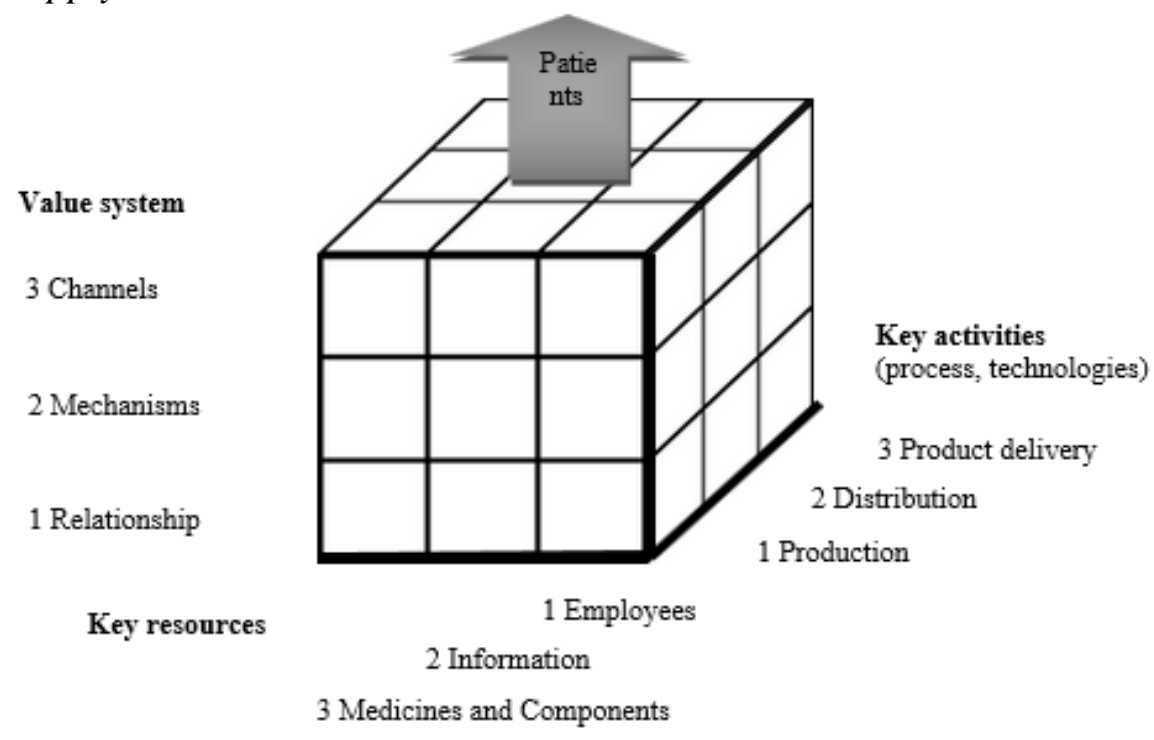

Source: Authors' estimations.

\section{Evolution of Business Model}

Business model may be changed over time period because of new business landscape. Transformation from existing business model to one, which respect society, requires behavior change (Figure 2). This change will need competencies inside the company, also, the presence of relations among the managers of departments, which are linking new business model between activities of each department, helps for behavioral change. Business model elements then could be replaced with another element or splitted i.e., separated into new business model elements.

Figure 2. Transformation Process Stages to Collaborative Enterprises Model

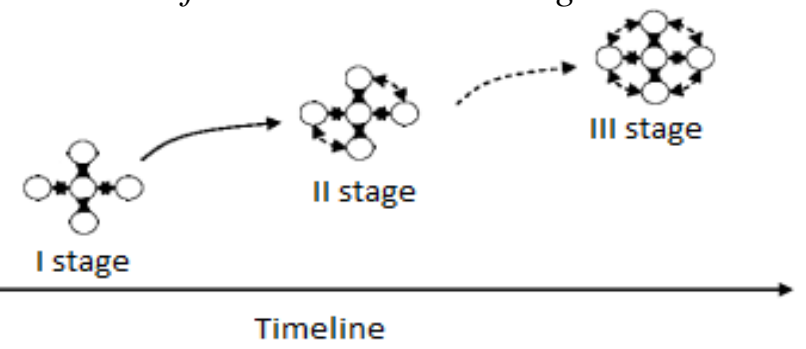

Source: Authors' estimations.

First stage represents low collaboration and integration between distribution channel partners. Second stage is intermediate period where strategic actions are lunched to reach higher collaboration and integration level. And third stage shows intensive collaboration and integration in distribution channel with focus of these strategic actions to patient needs. This stage allows to share demand related data intensively. 
Changes in the business models seem to have significant changes in the global competitive environment. Changes in relationship linkages between parties or their units affect the output of distribution channel activity. Business model improvement setup involves updates of relationship linkages among firms and require transformational behavior to reach impact of the setup. Business model evolution shows dramatical changing since the 1933s:

- Standalone organization is mention around the 1933s. The framework depicts the business as system containing cause and effect relationships (Baden-Fuller and Haefliger 2013).

- Function driven organization is visible from 1937, especially then decentralized functions of company were switched to centralized strategic functions. Herein also static and dynamic view to the functions exists (Demil and Lecocq 2010).

- Process driven production and operations (1958) have been instituted to serve the diversity of demand with respect to time and place. According the author McGrath (2010) two core components constitute business model: the basic "unit of business", which is what customers pay for, and "key metrics" of process for delivering competitive performance.

- Network organization is evident from 1980. The business model was developed to point out the competitive advantages. Outsourcing of many support functions such as distribution were fully or partly implemented under this time period. The role of specialized distributors has increased during this time period.

- Finally, collaborative enterprise model is highlighted in literature from 2010. It represents system with intensive relationships between entities.

It becomes necessary to search solutions that enable the strengthening business model of pharma enterprise. Collaboration is seen both from a resource-based and knowledge-based perspective. The most common motive for collaborative relations is the positive effect on shortage reduction. Below is presented the evolution of business models (Table 1).

The step from the "classical" B2B approach to the new multi-tier B2(B2B) concept requires the development of all activities centrally designed and therefore communications between various entities. Business needs real cooperation, more than minimal collaboration and compliance. Collaborative purpose - not the expression of enterprise but is the delivery of service for citizens, like the guidelines for every employee in the company to do the best activity. It is the description of efforts expected in all levels of company: from top managers and their provided business strategy, to unique all employees' partnership, and further down to teams of the departments and their efforts on process improvement.

Value Compass suggests starting discussion on new model, i.e. employeesto-patient model development, as the system of activities and system of relations between parties (Adler et al. 2011) to outline employees and patient's relationship. It can reinforce the degree of protection of patients' rights and can be a tool to ensure patients' rights realization. 
Table 1. The Evolution of Business Models

\begin{tabular}{|c|c|c|}
\hline Direction & Business models & Drugs supply case \\
\hline $\begin{array}{l}\text { Standalone } \\
\text { organization } \\
(1933)\end{array}$ & $\begin{array}{l}\text { Business reference model is } \\
\text { concentrating on } \\
\text { organizational and } \\
\text { functional aspects of main } \\
\text { business activities inside the } \\
\text { organization. }\end{array}$ & $\begin{array}{l}\text { Cameroon example. The roads during } \\
\text { the rainy seasons do not satisfy } \\
\text { required conditions. This causes } \\
\text { increasing delays and difficulties } \\
\text { getting drugs' deliveries to the most } \\
\text { of places (Pharmalink 2011). }\end{array}$ \\
\hline $\begin{array}{l}\text { Function driven } \\
\text { organization } \\
(1937)\end{array}$ & $\begin{array}{l}\text { Activities are implemented } \\
\text { in departments and requires } \\
\text { coordination among } \\
\text { departments. }\end{array}$ & $\begin{array}{l}\text { Tanzania epidemic case in } 2009 \text { with } \\
\text { the implementation of treatment } \\
\text { stock tracking system (Leiras et al. } \\
\text { 2014) could be an example. }\end{array}$ \\
\hline $\begin{array}{l}\text { Process driven } \\
\text { organization } \\
(1958)\end{array}$ & $\begin{array}{l}\text { Activities are implemented } \\
\text { according service or product } \\
\text { flow to customers. }\end{array}$ & $\begin{array}{l}\text { Benin example. Here distribution } \\
\text { channels are leveraging on Coca- } \\
\text { Cola distribution chain. This chain is } \\
\text { available in every village and at the } \\
\text { right condition for the end users and } \\
\text { has strong tracking system impleme- } \\
\text { nted in remote access, which miti- } \\
\text { gates the risk to miss drugs in areas. }\end{array}$ \\
\hline $\begin{array}{l}\text { Network } \\
\text { model (1980) }\end{array}$ & $\begin{array}{l}\text { This cross-functional and } \\
\text { cross-firm model developed } \\
\text { to aiming to integrate the } \\
\text { key business processes. }\end{array}$ & $\begin{array}{l}\text { Pharmaceutical firms started to use } \\
\text { logistics service providers, which give } \\
\text { lower distribution costs in delivering } \\
\text { products to end users. Their system } \\
\text { holds permanent buffer stock at } \\
\text { warehouses, and respond to the needs } \\
\text { of patients in periphery, also improves } \\
\text { organization access to drugs } \\
\text { (Pharmalink 2011). }\end{array}$ \\
\hline $\begin{array}{l}\text { Collaborative } \\
\text { enterprises } \\
\text { model (2011) }\end{array}$ & $\begin{array}{l}\text { The model is client centric } \\
\text { and covers collaborative } \\
\text { functions, which are } \\
\text { implemented in processes of } \\
\text { functioning subsystems. } \\
\text { Model covers the alignment } \\
\text { of large system (collaborating } \\
\text { firms) processes, which } \\
\text { interconnect employees of } \\
\text { many sub-systems. }\end{array}$ & $\begin{array}{l}\text { Stocking of the widest possible range } \\
\text { of pharmaceuticals, easy access of } \\
\text { inventory via partners, integrated } \\
\text { production and efficient distribution } \\
\text { system, guaranteeing frequent and } \\
\text { timely deliveries to pharmacies } \\
\text { (Kanavos et al. 2011). Wide shift to } \\
\text { the model is foreseen in } 2030 \text {. }\end{array}$ \\
\hline
\end{tabular}

Source: Authors' estimations.

Value Compass, which guides to the main direction, suggests recognizing the challenge given and expecting from every employee the responsibility to meet it every day. To shift these aspects, knowledge of organizational behavior, industrial organizations, and transaction cost theory is needed.

Organization is the set of units, which performs key activity. The key activities performed by company and its partners are considered as the part of business model. Transactions are supplemented among activities and represent the second linkage in business model. The result of transactions is products (i.e., medicines) flow to the patients. 


\section{Distribution System to Meet Patients Needs}

\section{Distribution System}

Distribution channel operates as system, which needs to focus on patients needs. The system in differentiated volume vice. In large scale manufacturing supply case production and consumption are co-located. Examples include regenerative cell-based therapies in healthcare and other cases. In smaller scale manufacturing supply case production is located close to the point of use. New changes are evident in medicines distribution: from tradition channels, which contain large scale production, resulting inflexibility and low inventory situations, to modern channels, which respond to individual consumer demand signals requiring delivery to a specific location of consumer choice (i.e., pick up point), rather than far away healthcare locations.

Figure 3. Alignment of Business Model for Medicines Distribution
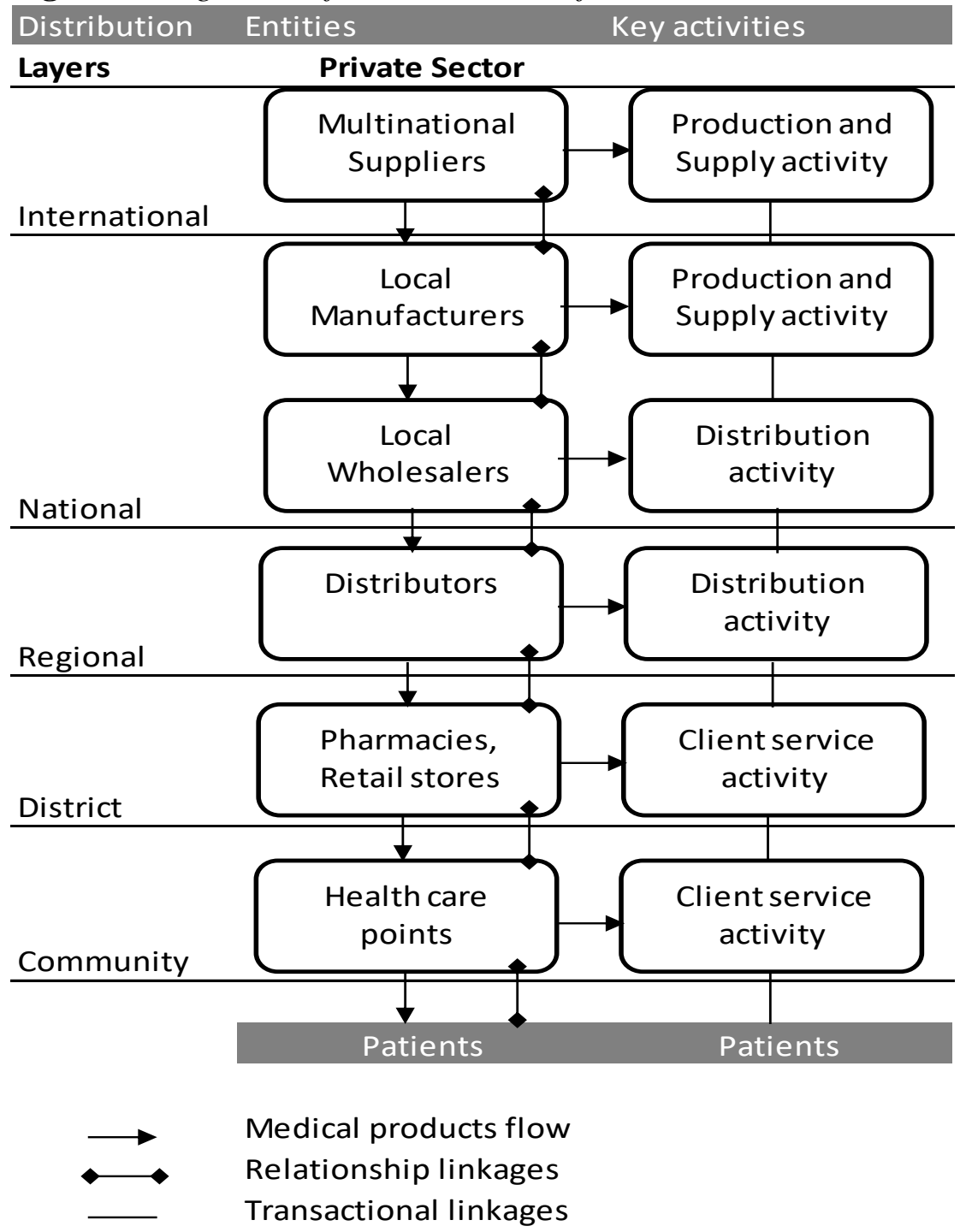

Source: Authors' estimations. 
Figure 3 presents the presentation of business model for medicines distribution. Based on discussion on business model, companies have relational and transactional linkages, which are integrated into unique distribution system delivering results to patients (Figure 3).

Local wholesalers buy and sell on their name and take over the full collection risk towards our customers. Regional distributors could handle pure fee service, in which all services are performed on the seller's name. For collaborative enterprise the common purpose to serve patients must become the daily routine for humans performing different functions and employed at various levels of organizations to overcome new challenge together. In particular, to align large system of collaborating enterprises, and their processes, interconnecting employees in the system (i.e., the organizational structure units).

\section{Motivation to Use Recent Business Model: Legal Aspects towards Patients}

Drug shortage has negative impact on patients' accessibility to the medicine and medical treatment. The role of drugs storage takes significant place and impact to safeguard the access to the medicine. There are variety of factors influencing the storage and supply of the drugs.

The importance to ensure the rights of patients the accessibility to health care, right of access to preventive health care and the right to benefit from medical treatment depends on national health system, and supply, storage chains. Patients must be accorded by qualified health care and patient's rights law is intended to secure good medical practice and access, supply and storage to medicinal products. Each of the national health systems of the EU countries manifests quite different realities with respect to patients' rights and legal regulation to ensure the appropriate defense of patients' rights.

The distribution and supply are an important part of the quality that ensures that the quality of medicines is maintained at all stages of the distribution channel, from the place of manufacture to the pharmacy or the person authorized to supply medicinal products to the customers. There are specific European Union (EU) law regulations that defines the principles and good practice for the medical products distribution. European Union Member State's follow with requirements and authorized institutions organize and coordinate the supply of the state population with the basic medicinal products, regulate and ensure by legal and organizational measures uninterrupted supply to the pharmacies of the country of the quality, safe, effective, basic medicinal products.

At the EU law regulation level for wholesale distribution, authorized holders of medicinal products obliged to follow the European Commission Guidelines on Good Distribution Practice of medicinal products for human (GDP) (2013). GDP (2013) are based on Article 84 and Article 85b (3) of Directive on the Community code relating to medicinal products for human use (2001). Revised were published in order to consider recent advances in practices for appropriate storage and distribution of medicinal products in the European Union. Hence "the new requirements introduced by Directive Community code relating to medicinal products for human use, as regards the prevention of the entry into the legal 
distribution channel of falsified medicinal products (2011), that amending Directive on the Community code relating to medicinal products for human use (2001)".

Article 81 of Directive on the Community code relating to medicinal products for human use (2001) states "that the holder of a marketing authorization for a medicinal product and the distributors of the said medicinal product actually placed on the market in a Member State shall, within the limits of their responsibilities, ensure appropriate and continued supplies of that medicinal product to pharmacies and persons authorized to supply medicinal products so that the needs of patients in the Member State in question are covered".

Wholesale distribution of medicinal products is an activity involving the procurement, holding, supply or export of medicinal products, unless such action carried out for the purpose of selling or dispensing medicinal products to the public or patients. GDP (2013) prescribe, "procurement as a receipt or purchase, and therefore the purchase and sale of medicinal products without requiring them to be received and stored is a wholesale distribution activity requiring a license". It also does not matter where the distributor is established (in specific parts of the customs territory, such as free zones or free warehouses) and operates (stores, supplies or exports) the requirements to have a wholesale distribution authorization and to operate are applied to the distributor.

As an example, might be taken persons who deal with the mediation of medicinal products and drugs on the territory of the Republic of Lithuania, who have their place of residence and place of work and contact persons in accordance of the Republic of Lithuania Law on Pharmacy (2006), are registered by indicating them at the list of suppliers. All suppliers must act in accordance with the relevant requirements of the GDP (2013).

The requirements for the quality system, personnel, premises and equipment, documentation, operations performed (for the selection and validation of suppliers, for the assessment of recipients, the acceptance, storage, stock management, supply, including transportation), for handling complaints, suspected counterfeits, returns and cancellations, contractual activities, internal audits, implemented by the authorization holder of wholesale distribution specified at GDP (2013). The legal act defines "the quality management principle of all critical stages and significant changes to be identified, justified and, where appropriate, validated". Wholesale distributors must maintain a quality system setting out responsibilities, processes and risk management principles in relation to their activities and wholesale distributors must ensure they supply medicinal products only to persons who are themselves in possession of a wholesale distribution authorization or who are authorized or entitled to supply medicinal products to the public.

Recommendation provided by the GDP (2013) is to follow of the ICH Guideline Q9 on Quality Risk Management (QRM) (2006) for quality risk management, as recommended by the International Conference on the Harmonization of Technical Requirements for the Registration of Medicinal Products for Human Use. QRM (2006) defines "principles and examples of tools for quality risk management that can be used to various aspects of pharmaceutical quality". These aspects include development, manufacturing, distribution, and the 
inspection and submission/review processes throughout the lifecycle of drug substances, drug (medicinal) products, biological and biotechnological products all the chains of supply.

Good Distribution Practice certificates are issued by the EU Member State authorities, which reveals that the evaluation of wholesale distribution authorization holder corresponding with the requirements. The data of pharmaceutical wholesale distribution authorizations with following procedure established by the European Commission, Good Distribution Practice certificates and the noncompliance with requirements for each EU Member State indicated in the EudraGMDP database of the European Medicines Agency. EU law legislation uniform and harmonize law, as well provide common standards for EU Member States.

\section{Patients' Right Protection in the Context of EU Anti-Discrimination Law}

Patient's rights are protected in the field of European Union antidiscrimination law. The supply and storage of the drugs influences the access to the goods and services.

The law of regulation of patients under the influence of modern globalization in any country appears to be very significant from the point of view of local and international policy. There is the difference between legal regulation and protection against discrimination in the EU level and separate legal regulation of each Member State.

The Member States of the EU are required to ensure that the national legislation must comply with the requirements of anti-discrimination law and to make all changes of the national legal regulation that are needed. With the provisions of the anti-discrimination law, all patients living in the European Union could benefit from effective legal protection against the discrimination, irrespective of their nationality to the access to the goods and services with the extension to the medicine and drugs.

The progress of EU equality law in the last years developed from a market right to a social and after that to fundamental right. Non-discrimination legislation provide two legal acts promoting equality in sense to access to goods and services including healthcare and access to the drugs. Under EU law, protection from discrimination in the field of access to the supply of goods and services, including housing, applies to the ground of race under the Racial Equality Directive (2000), and to the ground of sex under the Gender Goods and Services Directive (2004).

Racial Equality Directive (2000) introduced prohibition of discrimination based on race or ethnicity in the context of employment, but also in accessing the welfare system and social security, as well as goods and services. It prohibits the following forms of discrimination: direct and indirect discrimination, harassment and instructions to discriminate. This was a significant expansion of the scope of non-discrimination law under EU law. In 2004, the Gender Goods and Services Directive (2004) extended the scope of discrimination to the area of goods and services. The difference between protected areas and grounds of antidiscrimination law cause the different level of protection. Gender Goods and Services Directive (2004) gives more precision to prohibition of discrimination, 
stating that it relates to all goods and services which are available to the public irrespective of the person concerned as regards both the public and private sectors, including public bodies, and which are offered outside the area of private and family life and the transactions carried out in this context. Although healthcare is covered specifically under the Racial Equality Directive, it may also fall under the scope of services, particularly where this is private healthcare. In this sense, the Court of Justice of the European Union (CJEU) has interpreted services in the context of free movement of services to cover healthcare that is provided in return for remuneration by a profit-making body. Unfulfilled demand of patients means abuse of their rights to get proper health treatment.

\section{Link between Business Model and Supply and Demand Shortage Causes}

The review of the literature dedicated to supply and demand shortage shows the links to research areas mentioned as elements in the business model. Just-intime (JIT) production has received a great deal of attention in the past two decades, due to aim to reduce lead time in the process. Ouyang et al. (2007) study develops an integrated inventory model assuming vendor-buyer relationships, which jointly determines lead time and the frequency of deliveries. Yang and Pan (2004) have studied the effect of lead time reduction. Yang and Pan (2004) offered integrated inventory model.

Rodado et al. (2017) proposed mathematical model with product mixing that considers shortage with one-month time period. Hidayat et al. (2012) investigated controllable buyer's lead time that can be shortened in product delivery by adding costs. Tayal et al. (2015) consider shortages as lost sales. They have stated that suppliers must pay for delays and compensate the losses for retailer. In addition, presented inventory model is tested with respect to various mechanisms parameters in concern to the number of warehouses and products. Jaggi et al. (2016) consider inventory system where cycle begins with shortage due to the lack of information.

There are some studies dedicated to information sharing and channel alignment. Ferrer and Ketzenberg (2004) acquire information sharing. They developed model to evaluate the impact of information sharing and supplier lead time on manufacturing costs. The model formulated with an infinite horizon. By using Markov decision process, they proved that the value of short lead times increases for products with higher complexity.

Huang et al. (2017) study considers linkages in two-echelon supply chain with multiple suppliers, with which information sharing is essential for shortage reduction and successive sales (i.e., demand) increase. Also, McCullen and Towill (2002) have studied information aspects in three-echelon supply chain. They pointed information transparency, lead time and time delays. Lee et al. (1997) point supply shortage and channel alignment also importance of information factor meaning demand and supply signal processing. Xiao and Shi (2016) focus on supply and demand and study the strategy of dual channel having potential shortage. All these aspects leads to shortage reduction and are important for traditional and pharmaceutical supply chains. 
In addition, some studies incorporate product specific attributes. Duong et al. (2015) study replenishment strategy with complex objective to minimize expiration rate with a given shortage rate. The inventory level, outdated quantity and shortage quantity are calculated according demand function. Where demand function represents the original product demand and the substitutable demand. Gan et al. (2017) provided channel analysis and assumed the demand as time dependent deterministic function for short life cycle products pattern.

There are studies including both production and distribution aspects. Memari et al. (2015) are minimizing the costs of production, distribution, holding and shortage costs representing out of stock situations. They have built the model which determines the green economic production quantity (GEPQ) and product shortages at dealers. Hidayat et al. (2012) highlights production aspect in shortage studies and assumes that during a production cycle the supplier produces a product and distribute it to the buyer facing a stochastic demand condition. In all abovementioned studies demand is treated as a function of unique product.

Chien et al. (2018) proposed model performs better than existing approach in minimizing the capacity cost loss of shortage for smart production. It is new working mechanism matching demand and supply and is suitable for advanced cases.

Grey et al. (2005) argument the idea that spot markets serve as a channel for suppliers as capacity and for buyers to address periodic shortages in relationshipbased supply chains. Also, Dolgui et al. (2018) observed that disruption of production capacity causes both product shortage and write-offs. The reliability of a multi-stage supply chain is evaluated as the probability that demand, and therefore enough product supply, can be met in multiple stations of transit within the time appropriate time frame. Herein, Dolgui et al. (2018) incorporated human factors in ripple effect analysis.

The most of these aspects are used for traditional supply chain. Pharmaceutical supply chain is more complex by environment and supply chain, which in most cases involves specialized distributors. Many of these situations are presented in drug supply cases under Table 2. Also, pharmaceutical supply chain is described as system with many risks leading to the growing problem of drug shortages. In addition, demand-driven supply has to be aligned for large scale and smaller scale manufacturing supply case production.

Table 2. The Studies Reflecting Research Areas, Matching the Structural Elements of Business Model

\begin{tabular}{|l|l|}
\hline Channels & Gan et al. (2017); Lee et al. (1997); Xiao and Shi (2016) \\
\hline Mechanisms & Chien et al. (2018); Tayal et al. (2015) \\
\hline Relationship & Grey et al. (2005); Ouyang et al. (2007) \\
\hline Employees & Awad et al. (2016); Dolgui et al. (2018) \\
\hline Information & $\begin{array}{l}\text { Ferrer and Ketzenberg (2004); Huang et al. (2017); Jaggi et al. } \\
\text { (2016); McCullen and Towill (2002) }\end{array}$ \\
\hline Medicines and Components & Awad et al. (2016); Rodado et al. (2017) \\
\hline Production & Chien et al. (2018); Hidayat et al. (2012); Memari et al. (2015) \\
\hline Distribution & Duong et al. (2015); Memari et al. (2015) \\
\hline Product Delivery & Hidayat et al. (2012); Volland et al. (2017) \\
\hline
\end{tabular}


It is not easy to figure out the reasons of drug shortage. Awad et al. (2016) stated that the root causes of products' shortages are complicated and involve many factors at the different nodes of the supply chain, including manufacturing issues, regulatory and legislative issues, supply and demand issues. In their study they identified the effect of manufacturing-related issues on drug shortages, the effect of distribution, the effect of supply and demand imbalance on drug shortages. They have also incorporated new category addressing human factor or behavior as a contributing factor to drug shortages. Their study results show:

- Regulatory and legislative processes were found the most contributing cause to shortages.

- Distribution (activity) factor was also identified as a contributor to the shortages.

- Human (resource) factor was also perceived as a significant contributing factor to drug shortages.

Authors identified that production (activity) issues were not significantly related to drug shortages in countries where production system is less risky due to such reasons. First, pharmaceutical production companies do not distribute medications directly to hospitals and health care facilities, this is done by specialized distributors. Second, raw materials are mainly purchased from international suppliers in enough quantities and reliable deliveries. Substitutes of the raw materials can be easily found in the international markets with prompt delivery if needed.

The study of Awad et al. (2016) did not incorporated information and products (resources) but these ones are evident from other studies presented. In addition, Volland et al. (2017) pointed the scheduling as supply constrain in hospital product delivery (activity).

The studies dedicated to shortage problem solving shows the link between research areas and business model. In most of the cases demand is incorporated as function of sales and presented on unique product level. And supply, which corresponds demand, must be prompt and work on the basis of shortened lead time, when it helps to reduce shortage. Shortage could be presented as imbalance between demand and supply, and is caused by production, distribution and products delivery (i.e., all these activities together meets value chain) issues where human factors and information sharing are important especially for complex products. To solve these causes various channels, mechanisms and relationship are analyzed in many studies. As pharmaceutical supply chain is very complex, all these aspects are incorporated in patientcentric business model. The main condition for the proper functioning of business model is collaborative enterprise. As business is becoming more complex, evolution of business model is important towards more collaborative enterprises supporting further progress, like smart production. Not many studies point the aspects such systems face to achieve zero shortage, so, these are expected in the future. 


\section{Research}

Methodology

As drug shortages are affected by supply and demand cases, pointed among major problems destroying patients' welfare, the research will be given to the improvement of drugs availability and the minimization of delays in drugs supply. The sequence of actions is important in distribution channel and could be analyzed from collaborative enterprises model perspective.

Many authors studied time constrain in distribution channel and delivered tools, demonstrating time metrics. Value Stream Mapping is one of the tools, which identifies time metrics such as lead time, value-added time, cycle time, and takt time (Lacerda et al. 2015). Dinis-Carvalho et al. (2015) proposed Waste identification diagram, which overcomes some of limitations of Value Stream Mapping and integrates the material flow and throughput time. It comprises two time constrains: time at workstations, and time for transportation activity. Rivera and Chen (2007) developed Cost-time profile, which represents cost and time investment important for production system. Cuatrecasas-Arbos et al. (2011) suggested Operation-time chart, which provides information on production and covers waiting time, and lead time. Time gap in distribution channel is the main constrain influencing delays or drug shortage cases.

The research purpose - to evaluate reasons of shortage. The aim of business collaboration is to take advantage of law of great numbers that helps better meet patients demand.

In the research authors are analyzing order lead time and reaction time to undeliveries. Automatization of order picking, and shipping process helps to reduce average order processing time. But it could be other factors disturbing order processing, like insufficient inventory level issues, etc. Usually, order processing time is 2 business days: the first business day - for order picking and the second business day - for order shipping.

The information about declined or partly declined Purchase order could be provided as soon as information become clear but not later than one business daytime interval. Parties could agree that if purchase order will not be $100 \%$ fulfilled, the supplier is responding to Purchase Order under the conditions agreed between Parties by sending Purchase Order Respond message (ORDRSP) containing information on Purchase order Line (item) level. These relationships are important aspects of business collaboration, as they interconnect sub-systems functioning based on information sharing. Automated electronic messages trigger new order generation event in the system, which sends the information to alternative supplier, for analog product, or different package item (Figure 4).

\section{Event Tree Analysis (ETA)}

The authors have taken historical data which show the shortage appearance: time series of shortage days, time series of order processing days and time series of order delivery days. Here authors have analyzed supply and demand causes. 
The identification of shortage reasons starts with the set of initiating events. An initial event is an event that creates the negative result that could lead to other events (intermediate events), and then finally is the outcome, which is mentioned above. Each initiating event leads to another event and continuing through this path.

Figure 4. Event Tree and Actions Taken to Avoid Drug Shortage

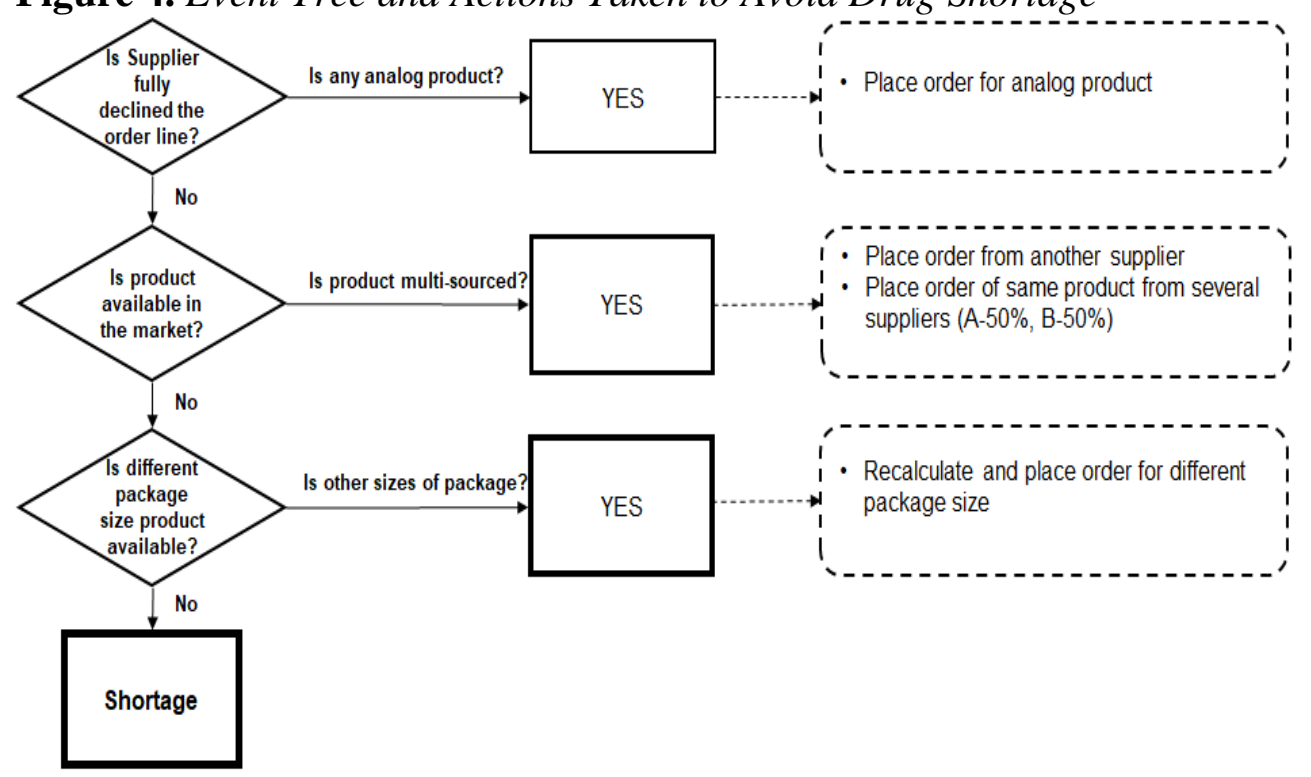

Source: Authors' estimations.

Steps to be taken to perform event tree analysis:

- Identify the event scenarios: Perform a system assessment to find failures scenarios within the system.

- Identify the initiating event: Use analysis to define initiating event.

- Identify intermediate events: Identify intermediate events.

- Build the event tree diagram.

- Recommend corrective actions: Minimize negative output by developing actions or alternatives.

The information about event provided timely stimulates the number of equally probable alternatives to be chosen to minimize the negative outcome. The selection decision is done immediately without time gaps and increases the opportunity overcome shortage case if selected alternatives has successful output reached by applying collaborative enterprises model.

\section{Time Horizon Formulation}

Distribution channel operates as system, which is driven by the sales (demand) of pharmacy to clients (i.e., patients). Pharmacy accumulates sales (demand needs) during the day places the order to distributor, and requests to bring it in 48 hours. At the end of the day, pharmacy has products available: if 
drugs are in stock, pharmacy continues serving clients. Orders arriving after the deadline could lead to shortage case.

Timelines are often used tool to represent the order of events. The timeline can be used to visualize durations and time gaps between events or overlaps of events. Timelines can use scale representing time. This scale is linear and dependent on the events in the row. It is suiting the subject and data and is multi-period in which single period intervals are represented gradually.

In multiperiod situation, necessary to define time horizon $-t$. The pharmacy places order on the day $t-2$. Distributor starts order processing in $t-1$ and ships it on the day $t$. What happens if distributor has no stock to process the order? If order delivery is not present at the evening of day $t$, when on the next day $t+1$ pharmacy places the new order with delivery day $t+3$. Finally, the order is arrived on $t+3$, and clients are served on $t+4$. The interval between $t+1$ and $t+4$ represents shortage period. This is the key point in rolling order processing situation. Authors presented case study which represents how collaborating enterprises could reach 6 days timeline instead of initial one with 7 days.

\section{Framework}

Each timeline has $\mathrm{n}$ number of order days, $n$ number of delivery days, and $n$ number of drugs availability days. Framework includes timeline with integrated ETA, actions taken to avoid drug shortage (placed under ETA), and system result analysis on the third day (stated in timeline scenario II referred in Figure 5). On the third day ETA is processed to avoid suppliers' failure case (mentioned in the event tree under initial event). System results are estimated by setting up "if-if" analysis approach to estimate availability of drugs. The research question - to define how the reduction of time period (i.e., move from 7 days timeline to 6 days timeline) effects the shortage reduction. The historical data of products is used to define the amount of order (i.e., order size). The order size is placed to be delivered in lead time frames. The lead time is defined is period from order placement to order delivery and is specific attribute of each unique product and is agreed with supplier on yearly basis. If the product is not delivered (i.e., undeliveries are fixed) by any reasons, the company must take new actions to serve its customers (i.e., patients). Reaction time is the time which is required for company to define steps to solve the shortage problem. Such period could be up to 4 days.

\section{Case Study}

The study case is provided to reach research purpose. The study covers one-month period (i.e., February) in the year 2019 and the analysis of 235 products behavior. All analyzed 235 products are commercial goods listed in the assortment as non-prescription drugs (medical products - products for eyes, hart, nerve, fish oil, vitamins, urine and hygienic products). Data is collected on above mentioned products from pharmacies, selling all mentioned products to customers. 
Shortage is calculated as sum of order lines (not delivered by supplier to pharmacies) which is divided from total number of order lines placed by all pharmacies.

The data was collected from pharma enterprise database. The enterprise is located in the Eastern part of Lithuania and has pharmacies in such regions: Vilnius, Ukmerge, Jonava, Utena, Radviliskis, Visaginas and Kedainiai region. Assortment placed under the 50 pharmacies $\left(\mathrm{N}_{1} \ldots \mathrm{N}_{50}\right.$, when $\left.\mathrm{n}=50\right)$ is slightly different due to the size of the pharmacy, but the authors have identified 235 assortment products being common in all 50 pharmacies.

Figure 5. Assortment Selection

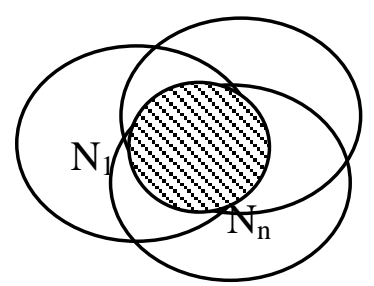

Source: Authors' estimations.

This paper is aimed to evaluate and establish the problem application intensity. The selected products (as presented in Figure 5) meet the common assortment criteria among region pharmacies.

\section{Findings/Results}

Timeline is very important aspect in order processing, as shorter it is as better for the clients (i.e., patients). In Figure 6 is presented the two timelines (longer one (I) and shorter one (II)). Both timelines have the shortage period, which length depends on scenarios:

I. Scenario represents shortage period i.e., interval between $t+1$ and $t+4$.

In first scenario parties (supplier and pharmacy) are following standard process: pharmacy is waiting for supplier delivery and only if drugs delivery is not appearing the action are taken to avoid drug shortage and new order is placed (following the steps presented in Figure 4).

II. Scenario represents shortage period i.e., interval between $t+1$ and $t+3$.

In case study bellow order processing time is 48 hours: the first 24 hours are given for order picking and the second 24 hours are for order shipping.

In second scenario supplier has responsibility to provide the information in advance about fully unfulfilled or partly unfulfilled order as soon as information become clear but not later than 24 hours. In this case pharmacy takes actions to avoid drug shortage one day earlier and placing new order is (following the 
steps presented in Figure 4). This second scenario shows the outcome of timeliness information sharing and higher level of collaboration between supplier and pharmacy. Authors also tried to measure what impact the actions taken in the second scenario has on shortage reduction.

By applying event tree analysis, authors selected undelivery cases which represents supplier failures and lasts from several days to certain period or repeats.

Figure 6. Timeline in Order Processing (I. 7 Days Timeline; II. 6 Days Timeline)
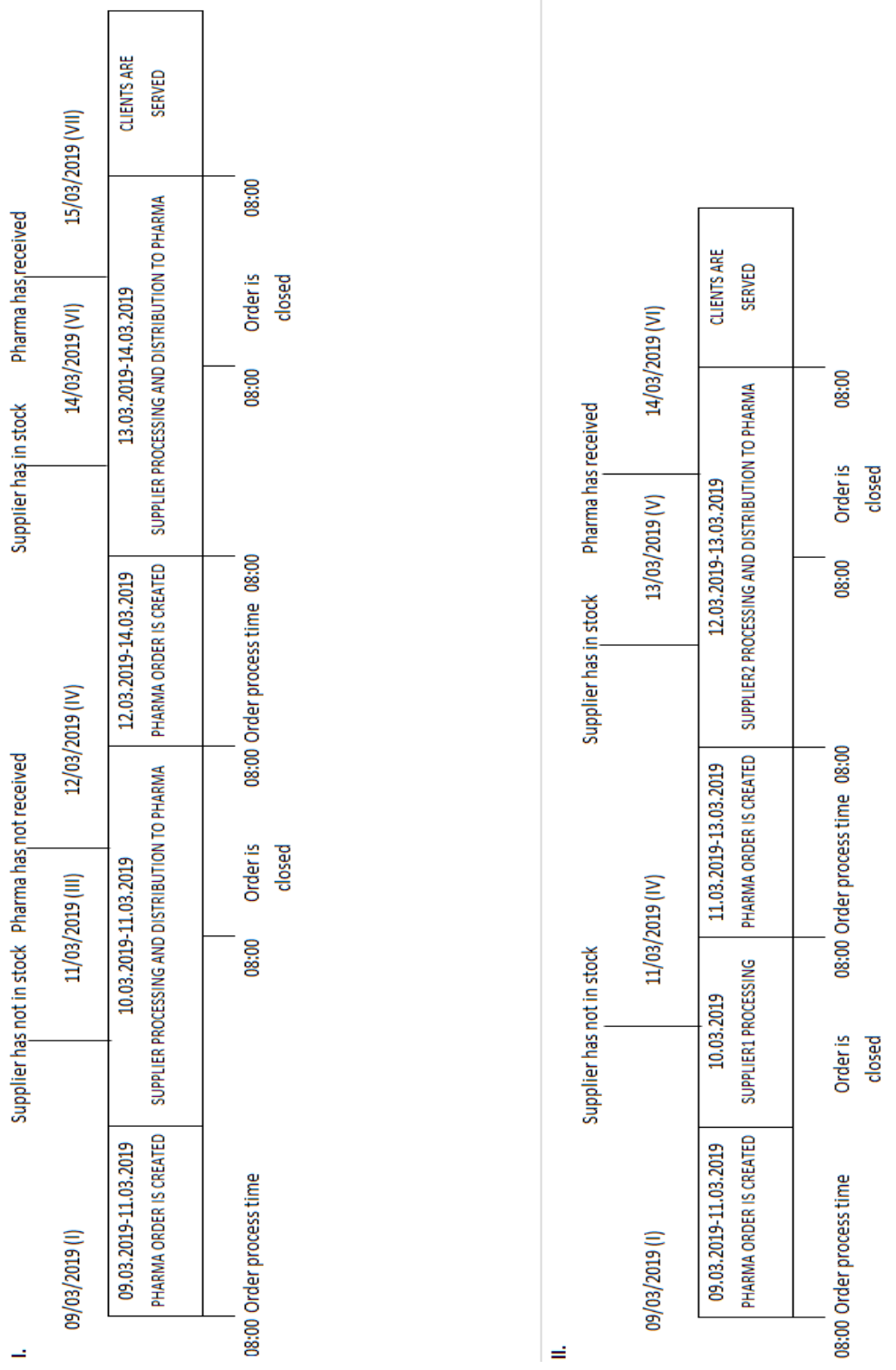

The lead time of deliveries (as specified in Table 3) varies for high demand, middle demand and low demand products selected for case study according Pareto rule. 
Table 3. Lead Time Parameters

\begin{tabular}{|l|c|c|c|c|}
\hline & \multicolumn{4}{|c|}{ Lead time distribution by duration } \\
\hline Products by demand & $\mathbf{1 ~ d a y}$ & $\mathbf{2}$ days & $\mathbf{3}$ days & More than 3 days \\
\hline High demand products (A) & $54 \%$ & 0 & $35 \%$ & $11 \%$ \\
\hline Mid demand products (B) & $58 \%$ & $26 \%$ & $11 \%$ & $5 \%$ \\
\hline Low demand products (C) & $66 \%$ & $27 \%$ & $5 \%$ & $1 \%$ \\
Source: Authors' estimations. \\
S
\end{tabular}

Most of deliveries are on Wednesday and Friday and the most of shortage is on Tuesday and Saturday. This is suggesting insights to revise suppliers' timetable and slightly reschedule delivery days. The highest shortage is for new products, as supply of these is not balanced nor from order timetable schedule, nor from supplier performance. That is why supply do not match the demand in most of cases when shortage appears.

In part of pharmacies which did not receive delivery from supplier product shortage could be $100 \%$ and in other part of pharmacies, which have the buffer stock the shortage will not appear. Moller's Junior, 45 psc., Carbon 300 mg, 20 tab., Magnis+B6 complex N30, A+E 30 tab., and Super Validol 60 mg, 10 tab. have the same shortage trend at the beginning of month, and it is twice lower than in Humer $150 \mathrm{ml}$ case or Super Validol case at the second part of the month. Statistically the constant number of pharmacies having indicated drug shortages, when reason of the shortage is supplier failure according ETA.

There is also systematic shortage which increases at 19th day (Tuesday) of the month for products having the shortage (following are evident in Figure 7). Moreover, supplier could revise delivery schedules from producer as at the same time various pharmacies struggle with high level of shortage if they do not have buffer for above mentioned products.

Authors have investigated that long timeline is directly linked with shortage cases. From lead time parameters analysis, we could see that for shortage reduction shorter timeline is the priority. The highest issue is on weekend as there are no deliveries from suppliers. In case the supplier is delivering less than ordered, new order is placed with one day time slot.

All analyzed 235 products are commercial goods (i.e., Super Validol, Magnis+B6, Moller, Humer, A+E, etc.). From Table 4 we could see that high demand products have 3.5 orders generated a week than such figure must be around 5 times. Average lead time is also quite long 9.4 days and supplier performance $-98 \%$, which is not good to have less than $100 \%$ for high demand products (A). In opposite, low demand products have average lead time 2.1 days. For some B products the lead time is up to 73 days. Long lead time appearance one of the factors leading to shortage increase. New products are lack of alignment and due to that faces shortage appearance (the statistics of shortage cases is summarized in Table 5). 
Vol. 6, No. 3 Bubliene \& Burinskiene: Supply and Demand Drug Shortage Causes...

Figure 7. Shortage Trendline for Various Products

Set EUROCARE SENS, 20 psc

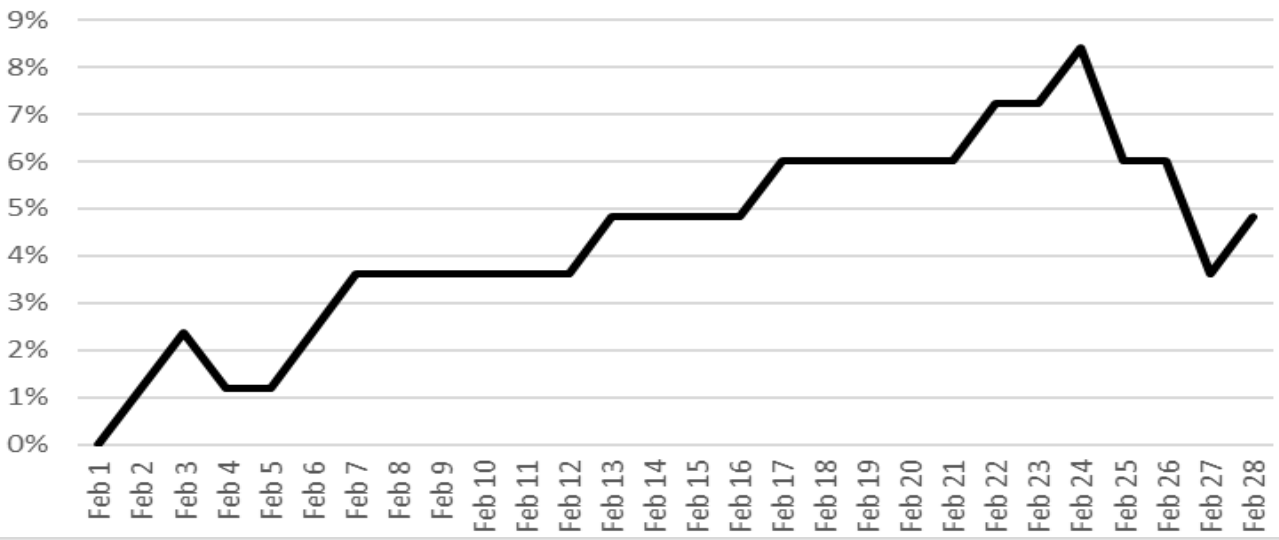

SUPER VALIDOL $60 \mathrm{mg} 10 \mathrm{tab}$

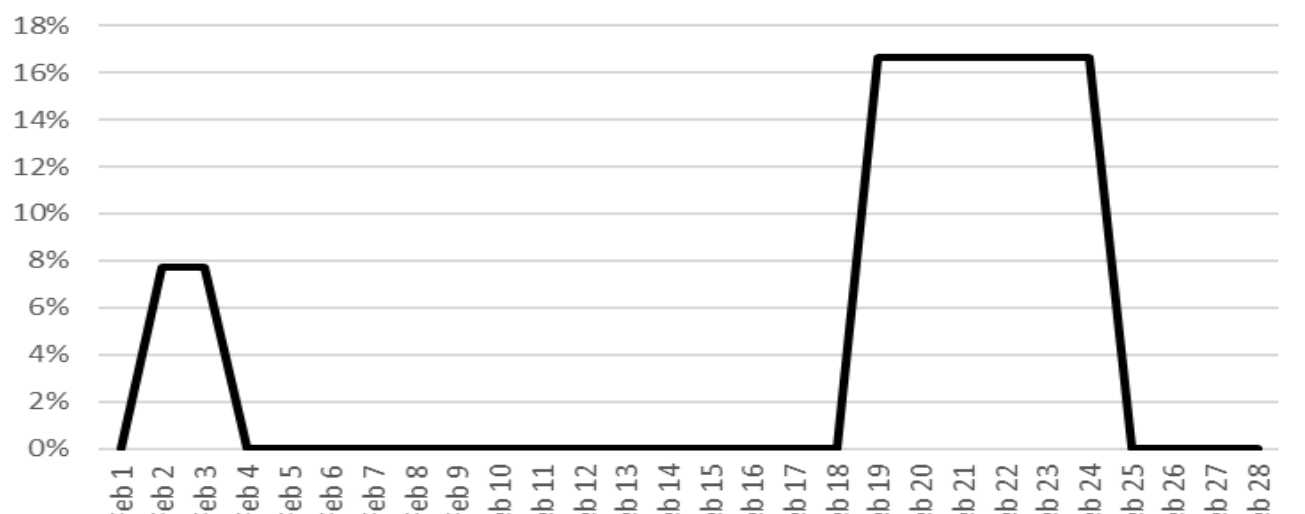

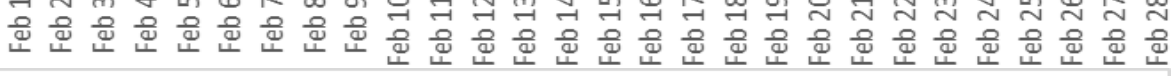

$$
A+E, 30 \text { tab }
$$

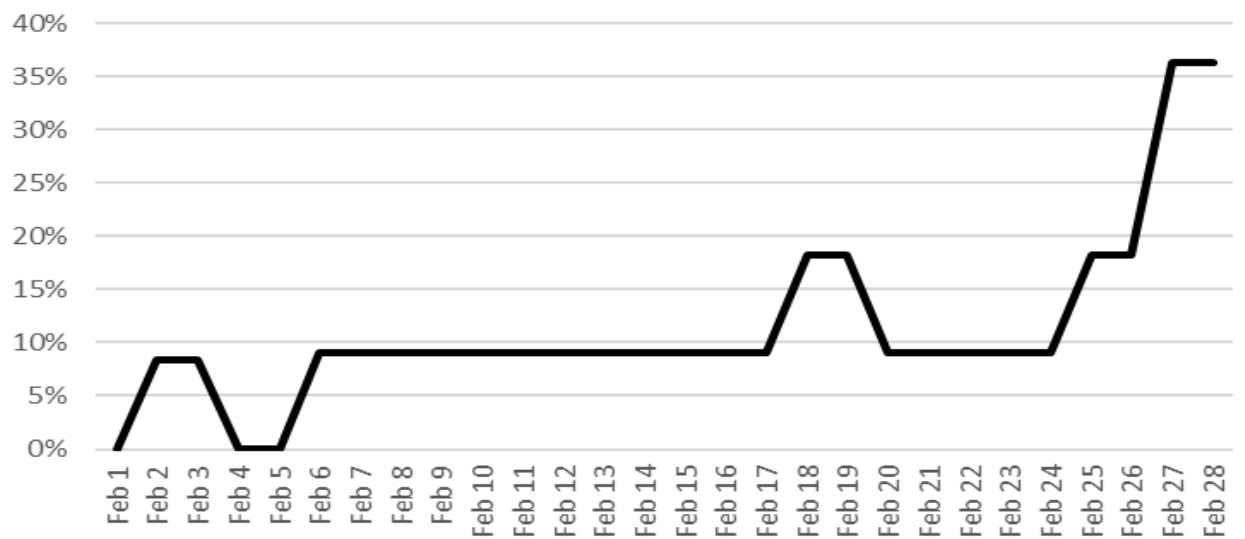


Table 4. Products Factual Parameters

\begin{tabular}{|l|c|c|c|c|}
\hline $\begin{array}{l}\text { Products by } \\
\text { demand }\end{array}$ & $\begin{array}{c}\text { Number of } \\
\text { products }\end{array}$ & $\begin{array}{c}\text { Generated } \\
\text { orders a week } \\
\text { (historical } \\
\text { data) }\end{array}$ & $\begin{array}{c}\text { Average lead time } \\
\text { (from order day } \\
\text { to delivery day) }\end{array}$ & $\begin{array}{c}\text { Supplier reliability } \\
\text { (quantity delivered vs } \\
\text { quantity ordered) } \\
\text { (historical data) }\end{array}$ \\
\hline $\begin{array}{l}\text { High demand } \\
\text { products (A) }\end{array}$ & 14 & 3.5 & 9.4 days & $98 \%$ \\
\hline $\begin{array}{l}\text { Mid demand } \\
\text { products (B) }\end{array}$ & 90 & 4.2 & 4.3 days & $100 \%$ \\
\hline $\begin{array}{l}\text { Low demand } \\
\text { products (C) }\end{array}$ & 121 & 1.2 & 2.1 days & $96 \%$ \\
\hline New products (D) & 9 & 1 & 28 days & $80 \%$ \\
\hline Grand Total & $\mathbf{2 3 5}$ & $\mathbf{2 . 4 8}$ & $\mathbf{1 0 . 9 5}$ & $\mathbf{9 7 \%}$ \\
\hline
\end{tabular}

Herein - undeliveries is opposite to supplier reliability. Undeliveries for A product is $2 \%$, for $\mathrm{C}$ products $-4 \%$, and for D products $-20 \%$. Finally, total undeliveries for 235 products is $3 \%$ (Table 4 ).

As supplier performance is not $100 \%$, order processing reduction by one day gives higher availability of stock upfront supplier's failure. This result might be explained by more frequent respond to demand.

Mainly orders are placed on morning and delivery is at the mid-day and shortage is fixed on the evening, - one day is required for responsiveness (reaction-time).

Table 5. Shortage size Statistics

\begin{tabular}{|l|c|c|c|c|}
\hline Summary of statistics & Minimum & Maximum & Mean & Standard deviation \\
\hline Shortage size & 0 & $33 \%$ & 0.015 & 0.034 \\
\hline
\end{tabular}

Source: Authors' estimations.

Linear regression was delivered to revise if products delivery is linked with shortage reduction. The study is delivered for the first week of the month and represented by weekdays. These results also confirm the importance of supplier delivery on weekday basis (Table 6). It also shows that shortage occurrence has higher correlation coefficient in the first part of week (i.e., at the beginning of cycle).

Table 6. Linear Regression Parameters

\begin{tabular}{|l|c|c|c|c|c|}
\cline { 2 - 6 } \multicolumn{1}{c|}{} & \multicolumn{5}{c|}{ Weekday } \\
\hline $\begin{array}{l}\text { Regression } \\
\text { parameters }\end{array}$ & Monday & Tuesday & Wednesday & Thursday & Friday \\
\hline $\mathrm{R}^{2}$ & 0.532 & 0.613 & 0.498 & 0.482 & 0.476 \\
\hline Intercept & 0.22 & 0.18 & 0.23 & 0.22 & 0.20 \\
\hline Slope & 0.78 & 0.82 & 0.77 & 0.78 & 0.80 \\
\hline Equation & $0.22+0.78 \mathrm{x}_{\mathrm{t}}$ & $0.18+0.82 \mathrm{x}_{\mathrm{t}}$ & $0.23+0.77 \mathrm{x}_{\mathrm{t}}$ & $0.22+0.78 \mathrm{x}_{\mathrm{t}}$ & $0.2+0.8 \mathrm{x}_{\mathrm{t}}$ \\
\hline
\end{tabular}

Notes: $s h_{t}$ : a shortage of period $t ; x_{t}$ : delivery on time of period $t$.

Source: Authors' estimations.

Table 7 represents the impact of delivery on shortage reduction for Tuesday shortage cases. 
Table 7. Regression Results for Equation

\begin{tabular}{|l|c|c|c|}
\hline Observations & $\mathbf{2 3 5}$ & Adjusted $\mathbf{R}^{2}$ & $\mathbf{0 . 6 5 3}$ \\
\hline Sum of weights & 235 & MSE & 0.084 \\
\hline $\mathrm{DF}$ & 233 & RMSE & 0.291 \\
\hline $\mathrm{R}^{\mathbf{2}}$ & 0.658 & MAPE & 13.70 \\
\hline
\end{tabular}

Source: Authors' estimations.

Below is the equation where delivery timeline directly linked with shortage:

$$
s h_{t}=0.1152+0.3265 s h_{t(-1)}+0.8168 x_{t}-0.2752 x_{t(-1)}
$$
(4.1442) (5.5005)
(19.574)
$(-4.2356)$

where $x_{t}$ represents the first scenario of delivery timeline and $x_{t(-1)}$ represents the second scenario of delivery timeline.

Figure 8 shows that if shortage appeares a day before, then there is the probability of $33.65 \%$ that it will occur on the next day. The equation (1) shows that on the day of shortage probability of delivery is $81.67 \%$. That means that those deliveries come at the end of a day not at the beginning thereof. If delivery occurs it diminishes probability on shortage next day by $27.52 \%$.

Authors have investigated that delivery timeline is directly linked with shortage cases. The reduction of timeline would help to generate more orders a week and delivery could be processed one day earlier following the actions mentioned under ETA, would have positive effect on shortage reduction.

Figure 8. Regression Variables Variants Decomposition

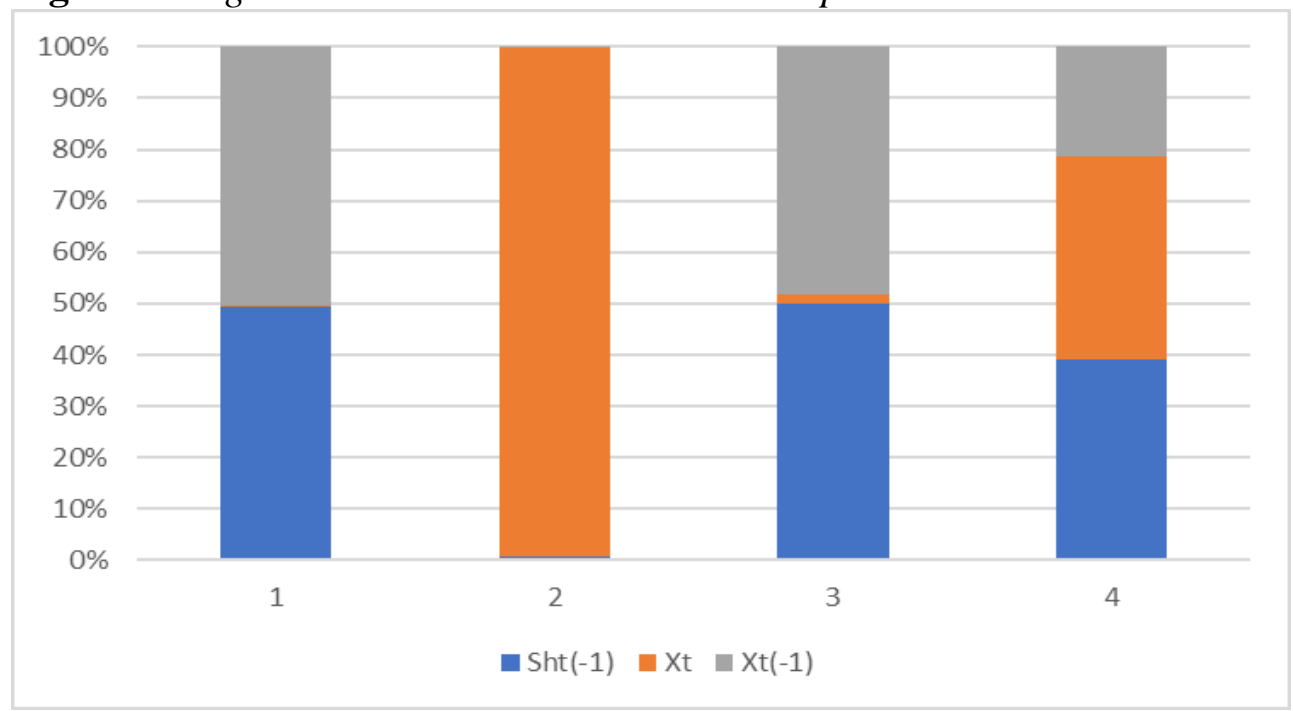

If there is no stock of product, when shortage appears and where is no demand on these days. Part of these shortage cases are linked to supply issues, which negatively affects representation of product demand. Presented equation shows that delivery is directly linked with shortage reduction but in order to avoid repeatable shortage cases, supply actions have to be unfront the demand days. The provided solution formulation could be treated as framework 
incorporating various aspects: time horizon and event tree analysis (ETA) for the reduction of shortage cases.

\section{Discussion}

Not all supply and demand cases, which are pointed among 7 major problems destroying patients' welfare, such as follows: production difficulties, the unavailability of raw material, recalls, business and economic issues, regulatory issues, supply activity related issues and disasters, are covered in the paper. The authors have concentrated on demand-driven supply and supply constrains such as resources, lead time and their alignment.

Under the study case the authors presented the the equation where delivery timeline directly linked with shortage. The regression method used in case study serves well then the effect of regressor manifests itself after more one one cycle (period). The decomposition of regression variables variants shows the effect of lead time shortening to shortage reduction, as the probability of delivery on the day of shortage is higher then $80 \%$. The timeline solution is valuable as it shows the probability to have shortage on the next day after delivery as well. This is because the delivery is too small, supplier delivery service level is week and the pharmacy shelfs are not filled up with products.

The timeline solution formulation is delivered taking into account the actions sequence and making choice between ETA alternatives. Moreover, the proposed framework presented in the the paper is not limited. It could be used to promote collaborative actions and allows the comparison of collaboration level between distribution channel partners (suppliers and pharmacies). The possible application of framework showed that the quantitative evaluation could be used to compare scenarios and it could be handled by single or multiple decision makers. The developed framework also could be useful for authors, which analyse drug shortage reduction cases under collaborative enterprise conditions.

\section{Conclusion}

Pharmaceutical supply chains are complex and facing new challenges. The studies are focus on traditional supply chain aspects and there are not many studies which place patient into the center position. To fill the gap authors constructed patient-centric business model for pharmaceutical supply chain enterprises and provided studies given to shortage avoidance problem which match the structural elements of business model.

Two main pillars are used for new business model development: pillar "who" targets channels, mechanisms, and relationship; and pillar "how" is specified as the system of resources and the system of activities, that is this pillar is presented on two axes. Finally, authors presented empirical study 
where examined the application aspects of business model for drugs and opportunities to minimize shortage.

The case study shows that lead time parameters must be revised for high demand products as they strongly correspond to the sales function. Opposite to high demand products, low demand products have shorter lead time parameters in presented case study. Also, supply chain for new products has to be tightened up, as in the most of cases supply constrains are critical for shortage avoidance: the reliability of suppliers is low, average lead time is long and the number of orders placed a week is very small.

The study showed that if shortage appeared a day before, then is the probability of $33.65 \%$ that it will occur on the next day. The equation shows that on the day of shortage probability of delivery is $81.67 \%$. That means that those deliveries come at the end of a day not at the beginning thereof. If delivery occurs it diminishes probability on shortage next day by $27.52 \%$. The empirical part of the study proves that time-period reduction could help to reach reduction of drug shortages. Performed empirical assessment showed that the suggested framework can be applied for drug shortage reduction.

The findings suggest the future research directions. The study results also give insights on necessity to have more frequent deliveries for high demand products, as now mid demand products have more frequent deliveries then high demand ones. The action to be taken for supplier timetable revision aiming to increase the number of deliveries and reduce shortage at the beginning of cycle; also, other supply and demand cases.

\section{Acknowledgments}

Our thanks to COST 15105 project for giving insights on research provided.

\section{References}

Adler P, Heckscher C, Prusak L (2011) Building a collaborative enterprise. Harvard Business Review 7: 1-9.

Alexopoulos E, Theodoulidis B (2003) The generic information business model. International Journal of Information Management 23(4): 323-336.

Alt R, Zimmermann HD (2010) Preface: Introduction to Special Section - Business Models. Electrical Market 11(1): 3-9.

Armenakis AA, Bedeian AG (1999) Organizational change: A review of theory and research in the 1990s. Journal of Management 25(3): 293-315.

Awad H, Al-Zu'bi ZBM, Abdallah AB (2016) A quantitative analysis of the causes of drug shortages in Jordan: a supply chain perspective. International Business Research 9(6): 53-63.

Baden-Fuller C, Haefliger S (2013) Business models and technological innovation. Long Range Planning 46(6): 419-426.

Biloshapka V, Osiyevskyy O (2018) Value creation mechanisms of business models: proposition, targeting, appropriation, and delivery. International Journal of Entrepreneurship and Innovation. Forthcoming. 
Chapman RL, Soosay C, Kandampally J (2002) Innovation in logistic services and the new business model: a conceptual framework. Managing Service Quality 12(6): 358-371.

Chien CF, Dou R, Fu W (2018) Strategic capacity planning for smart production: Decision modeling under demand uncertainty. Applied Soft Computing 68: 900-909.

Coomber R, Moyle L, South N (2016) The normalisation of drug supply: The social supply of drugs as the "other side" of the history of normalisation. Drugs: Education, Prevention and Policy 23(3): 255-263.

Cuatrecasas-Arbos L, Fortuny-Santos J, Vintro-Sanchez C (2011) The operations-time chart: a graphical tool to evaluate the performance of production systems-from batch-and-queue to lean manufacturing. Computer and Industrial Engineering 61(3): 663-675.

Demil B, Lecocq X (2010) Business model evolution: in search of dynamic consistency. Long Range Planning 43(2-3): 227-246.

Dinis-Carvalho J, Moreira F, Braganca S, Costa E, Alves A, Sousa R (2015) Waste identification diagrams. Production Planning and Control: The Management of Operation 20(3): 235-247.

Dolgui A, Ivanov D, Sokolov B (2018) Ripple effect in the supply chain: an analysis and recent literature. International Journal of Production Research 56(1-2): 414-430.

Duong LN, Wood LC, Wang WY (2015) A multi-criteria inventory management system for perishable and substitutable products. Procedia Manufacturing 2: 66-76.

European Commission (2013) Commission Guidelines 2013/C 343/01 on Good Distribution Practice of medicinal products for human use (GDP). Available at EUR-LEX https://ces.to/qWnAO3.

European Parliament and Council (2011) Directive 2011/62/EU on the Community code relating to medicinal products for human use, as regards the prevention of the entry into the legal distribution channel of falsified medicinal products. Available at EUR-LEX: https://ces.to/TmHp82.

European Parliament and Council (2004) Directive 2004/113/EC implementing the principle of equal treatment between men and women in the access to and supply of goods and services. Available at EUR-LEX: https://ces.to/NDfmUe.

European Parliament and Council (2001) Directive 2001/83/EC on the Community code relating to medicinal products for human use. Available at EUR-LEX: https://ces.to/1C2xIY.

European Parliament and Council (2000) Directive 2000/43/EC implementing the principle of equal treatment between persons irrespective of racial or ethnic origin. Available at EURLEX: https://ces.to/bhhchn.

Ferrer G, Ketzenberg ME (2004) Value of information in remanufacturing complex products. IIE Transactions 36(3) 265-277.

Gan SS, Pujawan IN, Widodo B (2017) Pricing decision for new and remanufactured product in a closed-loop supply chain with separate sales-channel. International Journal of Production Economics 190: 120-132.

Gordijn J, Akkermans H (2001) Designing and evaluating e-business models. Intelligent E-Business (July/August): 11-17.

Grey W, Olavson T, Shi D (2005) The role of e-marketplaces in relationship-based supply chains: a survey. IBM Systems Journal 44(1): 109-123.

Hidayat YA, Suprayogi S, Liputra DT, Islam SN (2012) Two-echelon supply chain inventory model with shortage, optimal reorder point, and controllable lead time. IEEE International Conference on ICMIT: 163-167. 
Hou J, Zeng AZ, Zhao L (2010) Coordination with a backup supplier through buyback contract under supply disruption. Transportation Research Part E: Logistics and Transportation Review 46(6): 881-895.

Huang YS, Hung JS, Ho JW (2017) A study on information sharing for supply chains with multiple suppliers. Computers and Industrial Engineering 104: 114-123.

Hwang J, Christensen CM (2008) Disruptive innovation in health care delivery: a framework for business-model innovation. Health Affairs 27(5): 1329-1335.

ICH Expert Working Group (2006) Guideline Quality Risk Management Q9 (QRM). Available from ICH: https://ces.to/9w5h9q.

Jaggi C, Khanna A, Nidhi N (2016) Effects of inflation and time value of money on an inventory system with deteriorating items and partially backlogged shortages. International Journal of Industrial Engineering Computations 7(2): 267-282.

Kanavos P, Schurer W, Vogler S (2011) The pharmaceutical distribution chain in the European Union: structure and impact on pharmaceutical prices. European Commission, Brussels, Belgium.

Kleindorfer PR, Saad GH (2005) Managing disruption risks in distribution channels. Production and Operations Management 14(1): 53-68.

Krumeich J, Burkhart T, Werth D, Loos P (2012) Towards a Component-based Description of Business Models: A State-of-the-Art Analysis. AMCIS 2012 Proceedings 19: 22-34.

Lacerda AP, Xambre AR, Alvelos HM (2015) Applying Value Stream Mapping to Eliminate Waste. International Journal of Production Research 54: 1708-1720.

Lee HL, Padmanabhan V, Whang S (1997) The bullwhip effect in supply chains. Sloan Management Review 38: 93-102.

Leiras A, de Brito Jr. I, Peres EQ, Bertazzo TR, Yoshizaki HTY (2014) Literature review of humanitarian logistics research: trends and challenges. Journal of. Human Logistics and Supply Chain Management 4(1): 95-130.

Lopez C, Sautmann A, Schaner S (2019) Does Patient Demand Contribute to the Overuse of Prescription Drugs?. The National Bureau of Economic Research. Retrieved from https://ces.to/eYQDHF.

McCullen P, Towill D (2002) Diagnosis and reduction of bullwhip in supply chains. Supply Chain Management: An International Journal 7(3): 164-179.

McGill A (2018) Business model canvas. Available at ASHTONMCGILL: https://ces.to/tVPVYU.

McGlinchey A, Toews T (2017) Seven Imperatives for B2B Digital Transformation Success. IBM. Retrieved from https://ces.to/JSY4Ac.

McGrath RG (2010) Business models: a discovery driven approach. Long Range Planning 43(2-3): 247-261.

MediMedia (2011) The Drug Shortage Crisis in the United States Causes, Impact, and Management Strategies. Retrieved from https://ces.to/cTnzvB./

Memari A, Rahim ARA, Ahmad RB (2015) An integrated production-distribution planning in green supply chain: a multi-objective evolutionary approach. Procedia Cirp 26: 700-705.

Moreau P (2017) New drugs in myeloma: beware of phase I trial results, beware of cost and demand for new trials. Leukemia 31(9): 18-43.

Newman DJ (2016) Developing natural product drugs: supply problems and how they have been overcome. Pharmacology and Therapeutics 162: 1-9.

Osterwalder A, Pigneur Y (2002) Business models and their elements. Paper for the International Workshop on Business Models, Lausanne, Switzerland. Retrieved from https://ces.to/6KIMQ7. 
Ouyang LY, Wu KS, Ho CH (2007) An integrated vendor-buyer inventory model with quality improvement and lead time reduction. International Journal of Production Economics 108(1-2): 349-358.

Pharmalink (2011) Effective pharmaceutical distribution channels on the road in low income countries. Ecumenical Pharmaceutical Network, Kenya. Available at: www.epnetwork.org.

Rivera L, Chen FF (2007) Measuring the impact of lean tools on the cost-time investment of a product using cost-time profiles. Robotics and ComputerInternational Manufacturing 23(6): 684-689.

Rodado D, Escobar J, García-Cáceres R, Atencio F (2017) A mathematical model for the product mixing and lot-sizing problem by considering stochastic demand. International Journal of Industrial Engineering Computations 8(2): 237-250.

Republic of Lithuania (2006) Republic of Lithuania Law on Pharmacy 78-3056. Available from E-SEIMAS: https://ces.to/5LPDdv.

Sabatier V, Medah I, Augsdorfer P, Maduekwe A (2017) Social business model design and implementation in developing countries: learning from an affordable medicine developed in Burkina Faso. Journal of Management Development 36(1): 48-57.

Schröder M, Falk B, Schmitt R (2015) Evaluation of cost structures of additive manufacturing processes using a new business model. Procedia CIRP 30: 311-316.

Sen KC, Natarajan VS, Mukherjee A (2016) An evaluation of the demand for orphan drugs as a response to promotional expenditures. In Let's Get Engaged! Crossing the Threshold of Marketing's Engagement Era: 853-853. Springer, Cham.

Settanni E, Harrington TS, Srai JS (2017) Pharmaceutical supply chain models: A synthesis from a systems view of operations research. Operations Research Perspectives 4: 74-95.

Shafer SM, Smith HJ, Linder JC (2005) The power of business models. Business. Horizon 48(3): 199-207.

Simonsen M, Skipper L, Skipper N (2016) Price sensitivity of demand for prescription drugs: exploiting a regression kink design. Journal of Applied Econometrics 31(2): 320-337.

Slywotzky X (1995) Value Migration. Boston: Harvard Business School Press.

Tayal S, Singh S, Sharma R (2015) An inventory model for deteriorating items with seasonal products and an option of an alternative market. Uncertain Supply Chain Management 3(1): 69-86.

Volland J, Fügener A, Schoenfelder J, Brunner JO (2017) Material logistics in hospitals: a literature review. Omega 69: 82-101.

Xiao T, Shi JJ (2016) Pricing and supply priority in a dual-channel supply chain. European Journal of Operational Research 254(3): 813-823.

Yang J-S, Pan C-H (2004) Just-in-time purchasing: an integrated inventory model involving deterministic variable lead time and quality improvement investment. International Journal of Production Research 42(5): 853-863. 
